\title{
Apuntes sobre Alain Badiou y el cine
}

\author{
Eduardo Laso"
}

Universidad de Buenos Aires, Argentina

\section{Resumen}

El presente artículo recorre algunas ideas principales de Alain Badiou en torno al cine, recogidas de diferentes textos a lo largo de su obra. Se propone entonces un recorrido por doce apartados: 1) el cine es un nuevo arte que nace en el siglo XX; 2) el cine es un arte de masas; 3) el cine es un arte ontológico; 4) el cine vuelve visible el tiempo; 5) el cine como el más-uno de las demás artes; 6) el cine es un arte impuro; 7) cada film es un objeto real singular, que expone el pasaje de una idea según la toma y el montaje; 8) el arte del cine como visitación de una idea; 9) el cine como escenario ético; 10) las tres maneras de hablar de un film; 11) un film es un punto-sujeto de una configuración artística; 12) del cine trágico al cine como imagen móvil de la eternidad. Estas ideas se presentan en articulación con diversas piezas cinematográficas: El nacimiento de una nación (Griffith, 1915), Pasaron las grullas (Kalatozov, 1957), El año pasado en Marienbad (Resnais, 1961), Muerte en venecia (Visconti, 1971), El movimiento falso (Wenders, 1975), Stalker (Tarkovski, 1979), Barton Fink (Coen y Coen, 1991), Odisea en el espacio (Kubrick, 2001), Joker (Phillips, 2019) y Nomadland (Zhao, 2020).

Palabras Clave: Alain Badiou | Cine | Filosofía

Notes on Alain Badiou and the cinema

\begin{abstract}
This article reviews some of Alain Badiou's main ideas about cinema, collected from different texts through his work. The writing is organized in twelve sections: 1) cinema is a new art that was born in the 20th century; 2) cinema is a mass art; 3) cinema is an ontological art; 4) the cinema makes time visible; 5) cinema as the most-one of the other arts; 6) cinema is an impure art; 7) each film is a singular real object, which exposes the passage of an idea according to the shot and the montage; 8) the art of cinema as a visitation of an idea; 9) cinema as an ethical setting; 10) the three ways of talking about a film; 11) a film is a point-subject of an artistic configuration; 12) from tragic cinema to cinema as a moving image of eternity. These ideas are presented in conjunction with various films: The Birth of a Nation (Griffith, 1915), Pasaron las grullas (Kalatozov, 1957), Last Year at Marienbad (Resnais, 1961), Death in Venice (Visconti, 1971), False Movement (Wenders, 1975), Stalker (Tarkovski, 1979), Barton Fink (Coen and Coen, 1991), 2001: A Space Odyssey (Kubrick, 2001), Joker (Phillips, 2019) and Nomadland (Zhao, 2020).
\end{abstract}

Keywords: Alain Badiou | Cinema | Philosophy

Para Alain Badiou, la tarea de la filosofía no es producir verdades sino señalarlas y volverlas composibles en los cuatro ámbitos en los que éstas acontecen: el arte, el amor, la ciencia y la política. Su obra filosófica pone en acto dicha concepción, recorriendo estos cuatro escenarios en los que se produce un acontecimiento-verdad. No es de extrañar entonces, que a lo largo de su obra se haya dedicado a reflexionar en torno del arte cinematográfico, en tanto su aparición en el siglo XX constituye un acontecimiento estético. El presente texto recorre algunas ideas principales del filósofo francés en torno del cine, recogidas de diferentes textos a lo largo de su obra.

\section{El cine es un nuevo arte que nace en el siglo XX}

A diferencia de las otras artes, que se remontan a los orígenes de la humanidad asociadas al culto religioso, el cine aparece en el contexto del capitalismo industrial. Y no nace del culto religioso, sino como curiosidad tecnológica, resultado del descubrimiento en el curso del siglo XIX, de la fotografía y otros dispositivos técnicos visuales. Estas invenciones hicieron posible la fabricación de aparatos ópticos que permitieran registrar y reproducir artificialmente imágenes en movimiento. En su inicio se presentó como una curiosidad que se transformó prontamente en entretenimiento popular. Desde este origen impuro y ateo, se fue consolidando también como arte. Un arte en el que a partir del registro de imágenes en movimiento, el director las monta para que advenga una idea-cine. Que después de tantos siglos haya aparecido un nuevo arte constituye, en sí mismo, un acontecimiento mayor del siglo XX.

\section{El cine es un arte de masas}

Badiou plantea que para que un arte sea de masas, debe ocurrir que las obras maestras de dicho arte -es decir, las

* lasale_2000@yahoo.com 
producciones artísticas que los expertos consagran como indiscutibles- sean vistas y amadas por millones de personas de cualquier grupo social, en el tiempo en que éstas aparecen. La pintura impresionista, por ejemplo, no fue un arte de masas en el tiempo en el que los principales referentes de ese movimiento pictórico presentaban sus obras. Y ciertamente el arte actual en el campo de la pintura o de la música contemporánea está lejos de ser arte de masas. Al contrario, está tan alejado del gusto masivo, que requiere de una formación estética previa para entender y disfrutar de dichas producciones estéticas. El cine, en cambio, fue tempranamente artístico, de vanguardia y masivo. Basta recordar los films mudos de la primera generación de grandes realizadores como Eisenstein, Epstein, Gance, Buñuel, Murnau o Lang, que aunaban experimentación formal y capacidad para atraer al gran público.

La aparición del cine es en ese sentido un acontecimiento paradójico para Badiou, ya que el siglo XX fue, en el campo de las artes, el siglo de las vanguardias, creando obras innovadoras de espaldas al gusto masivo. Pero al mismo tiempo fue el siglo del cine, el mayor arte de masas que haya existido.

\section{El cine es un arte ontológico}

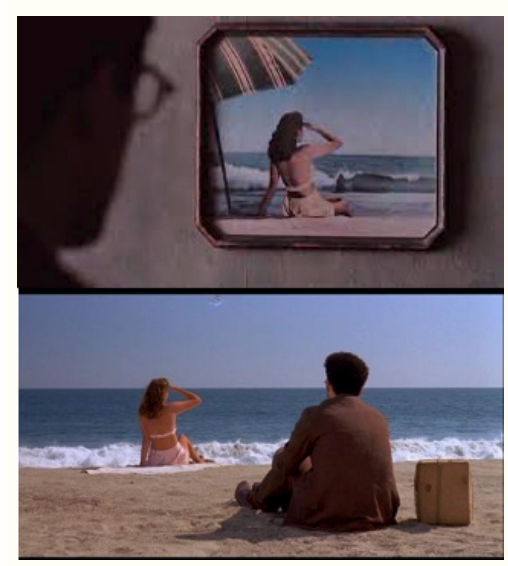

En el film de los hermanos Coen Barton Fink (1991), la puesta en abismo en la que Barton, fascinado con la foto de una mujer en la playa, termina al final incluido en la escena de la foto, plantea cinematográficamente la cuestión de las fronteras borrosas entre apariencia y realidad.

La ontología es la rama de la filosofía que se interroga por el ser del ente, aquello que hace que algo sea. Su eje de reflexión gira en torno de la distinción entre el ser (o lo real) y la apariencia. Dado que el cine es un arte que lleva al extremo lo visual como apariencia, inevitable- mente reintroduce el problema ontológico ya presente, por ejemplo, en el mito de la caverna de Platón. La sala de cine sería la recreación moderna del mito platónico: los sujetos ven sombras que toman como reales. El cine sería para Platón la culminación del arte como mimesis, es decir, como apariencia de verdad. Para el autor de $\mathrm{La}$ República, el arte se presenta bajo la forma de una apariencia de verdad inmediata sin fundamentación ni mediación del concepto. Una imitación del efecto de verdad que encanta por su carácter inmediato. Quien queda así fascinado, es prisionero de una apariencia de verdad, una imagen que desvía del trabajo argumentativo que propone el pensar filosófico. En el mejor de los casos, el arte cumple la función didáctica de exponer una verdad externa a él, bajo la forma de la apariencia sensible.

Lo que muestra un film ¿es un simulacro o es real? André Bazin, por ejemplo, lleva al extremo el planteo al afirmar que todo el cine clásico es cine documental, porque no importa que veamos una ficción, la cámara está registrando lo que tiene enfrente: los actores, los objetos, la escenografía. El cine es un arte ontológico porque partiendo de lo visible como apariencia, busca aquello que va más allá de lo visible, conectando la apariencia con lo trascendente de la Idea. Evoca así una dimensión ideal, a través del recurso inmanente de la imagen.

\section{El cine vuelve visible el tiempo:}

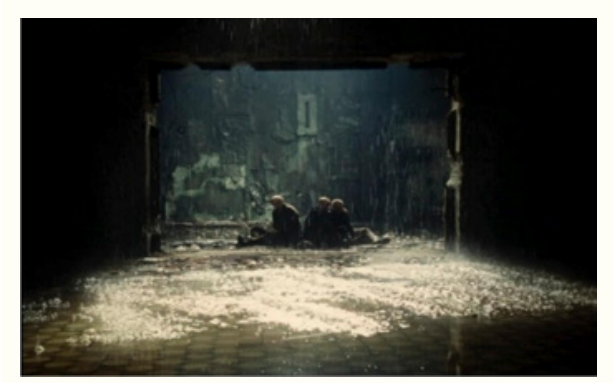

Un ejemplo de un cine que "esculpe en el tiempo" (es el título de uno de sus libros), es Stalker (1979) del director ruso Andrei Tarkovski. Narra el recorrido de tres personajes en torno de una zona devastada por un misterioso meteorito que terminó creando un espacio atópico en cuyo centro existe una habitación en la que se cumplen los deseos. Los planos secuencia acompasados en un escenario postapocalíptico, vistos hoy, constituyen una profecía del paisaje de desastre de Chernobyl.

Badiou retoma los planteos de Giles Deleuze a propósito del cine como imagen-movimiento e imagen-tiem- 
po. ¿De qué modo el cine construye el espacio-tiempo con imágenes? Mientras que la música hace audible el tiempo, el cine transforma el tiempo en percepción, volviendo visible el sentimiento del tiempo vivido. Y como además incorpora la música, hace también audible el tiempo. El cine es capaz de volver visible al tiempo como nunca antes lo experimentamos: tiempo detenido, lento, acelerado, retroactivo. Los recursos de la cámara lenta o acelerada, o de pasar la escena en reversa, configuran modos de "ver" el tiempo que sólo puede ofrecer el cine.

\section{El cine como el más-uno de las demás artes:}

Para Badiou, el cine no debe ser pensado como un séptimo arte que se suma a los otros seis. Si el cine toma elementos de la música, la danza, la pintura, la literatura, la arquitectura y la escultura, el resultado no es la suma de ellos. Un film no es literatura filmada, ni cuadros o estatuas en movimiento, ni baile, teatro o música con imágenes. Lo que hace el cine con las demás artes es sacarlas de su esfera propia para ponerlas al servicio del lenguaje cinematográfico. $\mathrm{Y}$ al hacerlo, incluye, integra y suprime las demás artes en el producto que es el film. Para eso, toma de las artes aquellos elementos accesibles y comunes de cada una, sin sus complejas condiciones de su producción.

De la pintura no toma la técnica del arte de pintar, sino la posibilidad de transformar la belleza sensible en imagen reproducible. Es la tarea a la que se aboca el director de fotografía, haciendo que la imagen de una película sea fascinante y adecuada a la narración. Baste recordar los claroscuros del cine policial o los colores pastel de las comedias musicales.

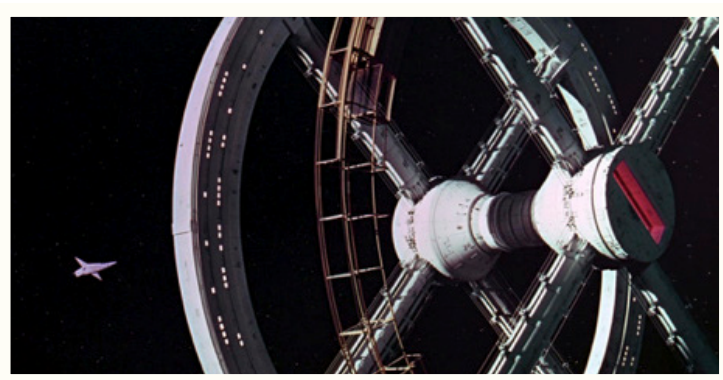

En 2001, Odisea del espacio, Stanley Kubrick hace un uso sorprendente del vals Danubio azul de Johann Strauss -una popular pieza de baile de salón del siglo XIX- para la escena futurista del ingreso de una nave a una estación espacial, convirtiendo los movimientos de las astronaves en un curioso y memorable ballet.

De la música no se interesa por los problemas de la composición musical, sino la musicalidad y ritmo que acompañan las vicisitudes de lo representado visualmente, otorgando así coloratura sonora. Compositores como Ennio Morricone, Alfred Newman, Bernard Herrmann, John Williams, Maurice Jarre o Miklos Rosza han compuesto memorables piezas musicales al servicio de películas, potenciando mutuamente la relación entre lo visible y lo sonoro hasta volverse inseparables. $\mathrm{Mu}-$ chas películas alcanzan su "aura” estética por la música que acompaña sus imágenes.

De la literatura sólo le interesa la narración de historias que puedan ser entendidas por el mayor público posible. De la arquitectura extrae la manera de organizar la espacialidad en una puesta en escena. Y del teatro toma el aura de los actores, para que devengan en estrellas de cine.

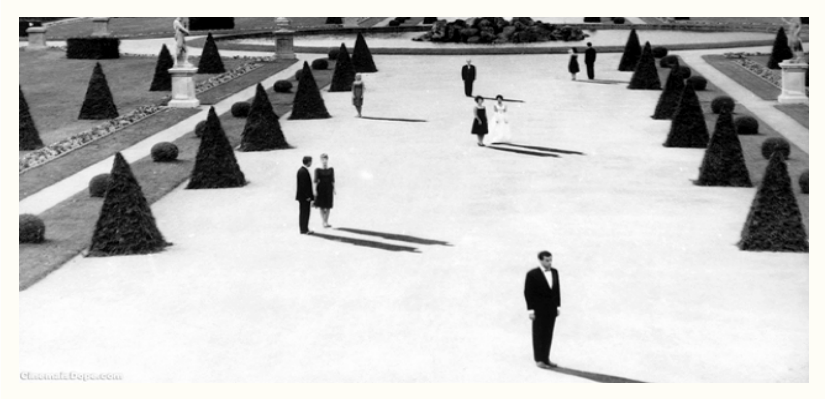

El año pasado en Marienbad, de Alain Resnais es una combinación fascinante de movimiento de cámara, disposición pictórica clásica de los planos, organización espacial del vacío, música que comenta los planos secuencia, y trama compleja y misteriosa. Uno de los films más extraños y bellos del cine.

\section{El cine es un arte impuro:}

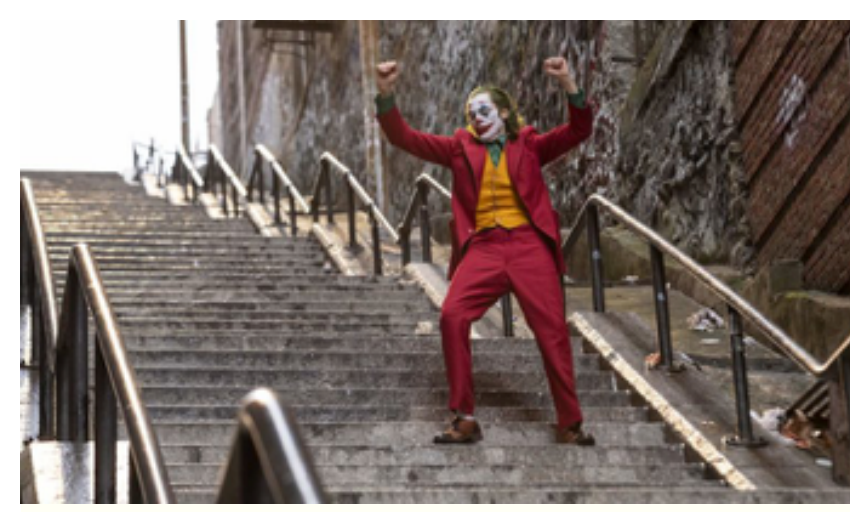

El film Joker (2019) de Todd Phillips, es un ejemplo de un cine que combina lo vulgar popular del no arte (el personaje mismo del Guasón no proviene de algún arte elevado sino de la historieta Batman) con la pretensión de una elevación estética, al ser tratado este personaje al modo de una tragedia contemporánea. 
A diferencia de las demás artes, el cine está cargado de no-arte. Incluso películas consideradas obras maestras del cine presentan imágenes banales, estereotipos, vulgaridades. Esta mezcla de pureza e impureza hace que el cine esté disponible para cualquier espectador, ya que le permite acceder al arte cinematográfico desde lo que no es arte. Pensemos por ejemplo el caso de muchas películas mediocres que en el transcurso de la misma presenta alguna escena en particular que la redime. Esto es imposible en el resto de las artes: un mal cuadro o una mala poesía no permiten ninguna elevación en el espectador. El cine, en cambio, permite alcanzar la pureza desde de la impureza, ofreciendo al público la posibilidad de una elevación.

\section{Cada film es un objeto real singular, que expone el} pasaje de una idea según la toma y el montaje

Lo real del cine para Badiou son los films. ${ }^{1} \mathrm{El}$ cine existe porque existen films, los cuales son el resultado de una doble sustracción: mediante la toma y el encuadre, el director el recorta una imagen de todo lo visible, para fijarla en el celuloide. Y de todo lo filmado corta y selecciona las tomas, para montarlas en una secuencia, conformando un discurso en imágenes. Lo que se llama "efecto Kuleshov", en honor al director de cine ruso Lev Kuleshov, que descubrió que la yuxtaposición de imágenes genera una relación entre ellas: al encadenarse entre sí, producen un efecto de sentido, del mismo modo que sucede con los significantes cuando se encadenan en una oración.

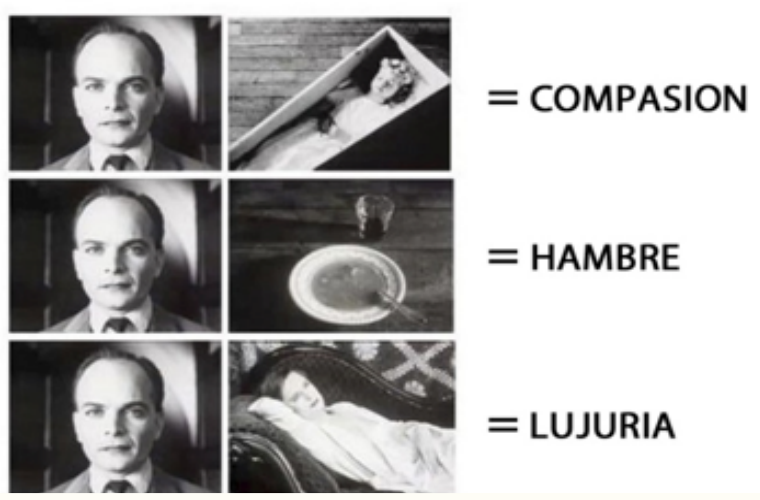

En 1918, Lev Kuleshov tomó de película antigua un plano de la cabeza de un actor ruso y la intercaló con tomas de un plato de sopa, una mujer en un ataúd y una joven en un diván. Cuando mostró la película, los espectadores significaron el rostro del hombre como compasión cuando quedaba asociado a la mujer muerta, como hambre cuando se asociaba a la sopa, y como lujuria cuando se seguía de la escena de la joven.
El efecto Kuleshov podría resumir para Godard la esencia misma del cine. El realizador francés, define al cine como el arte de la relación entre imágenes. Si la creación de imágenes es tan antigua como la humanidad, con la aparición del cine la imagen adquiere una nueva función: la de remitir una imagen a otras imágenes, y en última instancia a una red infinita de relaciones posibles entre ellas. ${ }^{2}$ De ese modo, el cine es el arte que nos hace comprender la conexión de una imagen con todas las demás. Para Badiou, el recurso de conexión entre imágenes permite la exposición de una idea al modo de un pasaje o visitación. Así, cualquier objeto en el cine, por el modo particular como queda capturado de un recorte, hace que aparezca al mismo tiempo en su singularidad y su idealidad: un tren en el cine es no sólo un tren, puede ser también el símbolo del progreso civilizatorio en un western, la fuerza violenta e impulsiva de un criminal en un film noir, o el curso inevitable del destino en un drama.

\section{El arte del cine como la visitación de una idea}

Badiou plantea que en el cine una idea se vuelve sensible a través de su pasaje o visitación. El término visitación refiere a la acción de ir a un lugar para conocerlo, y tiene también connotaciones religiosas cristianas: se lo emplea para referirse a la visita que según el evangelio, realizó la Virgen María su prima Isabel estando embarazada de Jesús. Con este término, Badiou plantea que en un film, la idea nos "visita" o aparece al modo de un "pasaje". La idea es en un film su pasaje o visitación, por efecto del anudamiento de tres movimientos:

- El movimiento local sustrae la imagen a ella misma, por lo cual la imagen pasa a ser otra cosa, además de lo que es.

- El movimiento de circulación impura por las demás artes produce superposiciones artísticas por las que habrá pasado la idea. 


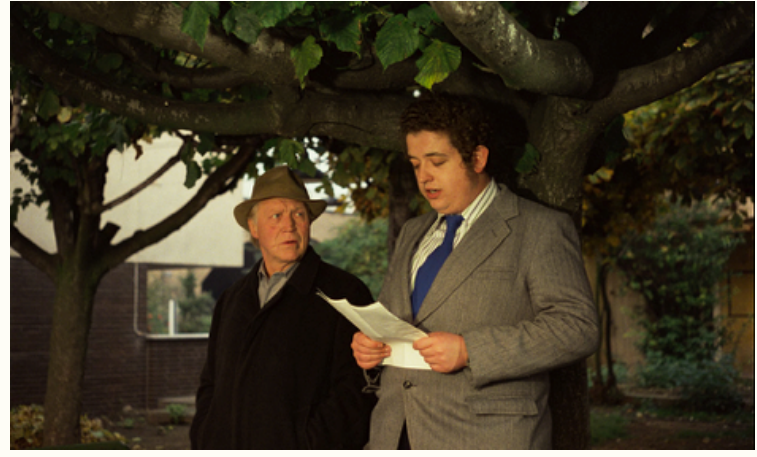

El movimiento falso (1975), de Wim Wenders, adaptación de la novela Wilhelm Meister.

Un ejemplo de este anudamiento para Badiou es la escena de El movimiento falso, de Wim Wenders, adaptación de la novela Wilhelm Meister, de Goethe, en la que un personaje lee por fin el poema que venía anunciando. A nivel del movimiento global, la lectura es un recorte sobre la carrera del grupo de personajes, instalando el poema por un efecto de interrupción, modo de pasar la idea de que todo poema es la interrupción de la lengua como herramienta de comunicación, representada en el film por la carrera de los personajes. A nivel del movimiento local, la turbación del lector, preso de la anulación de sí en el poema, tiene como efecto el asombro de existir. Y a nivel del movimiento impuro de las artes, lo poético en el film es el desgarramiento de lo poético del poema en el contexto de una escena cinematográfica.

\section{El cine como escenario ético}

El cine es un pensamiento en imágenes. Un pensar-cine que presenta una escenificación universal del acto, confrontado con los valores comunes. El cine nos ofrece las figuras típicas de los grandes conflictos de la vida humana, para hablar de guerra, pasión, justicia, verdad, coraje, amor, de modo que el espectador experimente la idea al mismo tiempo intelectual y emotivamente.

Por grande que sea, por imbricado que esté en nuestra época, ese arte de la aglomeración general se arraiga para siempre en el gusto de todas las clases, de todas las edades y de todas las naciones, para mostrar el espectáculo del poderoso al que un vagabundo rocía con agua de estiércol; el de un enorme navío que se hunde; el de un monstruo espantoso surgido de las entrañas de la tierra; el del Bueno que, a pleno sol, tras innumerables sinsabores, mata por fin al Malo; el del policía detective que atrapa al ladrón mafioso; el de las costumbres extrañas de los extranjeros y de los caballos en la llanura; el de los guerreros fraternos; el del drama sentimental y el de la mujer desnuda descuartizada por el Amor. Los más grandes artistas de este arte, Chaplin o Friedrich-Wilhelm Murnau, no hicieron más que poner de relieve esta procedencia vulgar, sin tratar jamás -muy al contrariode abolirla. (Badiou, 2004, p.281)

\section{Las tres maneras de hablar de un film}

Badiou distingue tres modos en que puede ponderarse un film. Llama juicio indistinto a evaluar una película en función de cómo fuimos afectados por ella: si nos gustó o no, si nos aburrió o entusiasmó, alternando entre el placer y el olvido. Se trata de una ponderación basada en la experiencia de haberla visto que suele predominar entre el gran público. Tal modo de evaluar es una declaración indistinta, ya que la regla del gusto no ofrece un criterio para distinguir si un film es o no una obra maestra.

El juicio diacrítico, en cambio, va más allá de la sensibilidad inmediata, para ubicar la singularidad de un film en el director, elevado al estatuto de autor, así como en los aspectos técnicos y de estilo de la película. Este juicio se funda menos en la experiencia del film que en un saber sobre del director, su obra y la historia del cine. Se trata del juicio del cinéfilo o del erudito, que pondera el buen gusto de una película desde un saber ya consagrado sobre lo "artístico", en el fondo un saber temporario que permite menos una historia del séptimo arte que una historia de lo que la crítica cinematográfica juzgó en su momento como artístico: "Cementerio de autores, la calidad designa menos al arte de una época que a su ideología artística. Ideología en la que siempre el verdadero arte es una ruptura" (Badiou, 2009, p.134).

La tercera manera de evaluar un film es el juicio axiomático, que considera al film en sí mismo, para examinar las consecuencias del modo propio en que una idea es tratada. ¿Cómo llega la idea la toma y al montaje en el film? ¿Cuáles son las consecuencias del modo en que trata esa idea? ¿Qué es lo que ese modo de ser presentada la idea nos revela de singular, que no podíamos pensar antes?

Badiou toma como ejemplo la travesía por los canales al comienzo de Muerte en Venecia de Visconti:

La idea que pasa -y que todo el resto del film sutura y disuelve a la vez- es la de un hombre que ha hecho lo que debía hacer en la vida, y que está entonces en suspenso, 
pendiente ya sea de un final, ya sea de otra vida. Ahora bien, esta idea se organiza gracias a la convergencia dispar de una cantidad de ingredientes: está el rostro del actor Dirk Bogarde, la cualidad particular de opacidad y de pregunta que este rostro acarrea y que depende, lo queramos o no, del arte del actor; están los incontables ecos artísticos del estilo veneciano, todos de hecho ligados con el tema de lo que está terminado, soldado, retirado de la historia, temas pictóricos ya presentes en Guardi o Canaletto, temas literarios de Rousseau a Proust; hay, para nosotros, en este tipo de viajero de los grandes palacios europeos, el eco de la incertidumbre sutil que traman, por ejemplo, los héroes de Henry James; está la música de Mahler, que es además la consumación distendida, exasperada, de una melancolía total, de la sinfonía tonal y de su maquinaria de timbres (que aquí son las cuerdas solas). Y podemos demostrar cómo estos ingredientes se amplifican y, a su vez, se corroen unos a otros, en una especie de descomposición por exceso, que justamente da la idea, como pasaje, y como impureza. (Badiou, 2009, pp.135-136)

\section{Un film es un punto-sujeto de una configuración artística}

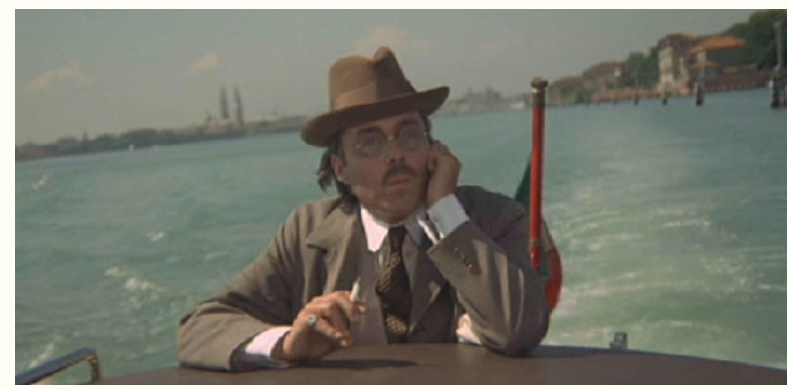

Dirk Bogarde en Muerte en Venecia (1971) de Luchino Visconti.

La obra de arte no aúna acontecimiento y verdad, como propone el romanticismo. Un film -como cualquier producto artístico- no es una verdad ni un acontecimiento, sino un punto-sujeto de una configuración estética. Para Badiou, toda verdad se origina a partir de un acontecimiento. En el campo del arte, una verdad estética es una configuración o procedimiento artístico iniciado por un múltiple singular de obras, que son los puntos-sujetos que constituyen un acontecimiento. En el arte la verdad inmanente y singular no es la obra ni el autor, sino la configuración artística iniciada por una ruptura aconteci- mental. Configuración que en el caso del cine puede tener por nombre "expresionismo", "neorrealismo" o "nouvelle vague”. Cada obra de una configuración artística es una indagación creativa sobre dicha configuración. ${ }^{3}$

Para Badiou, el arte es un procedimiento de verdad inmanente (el arte es las verdades que produce) y singular (sus verdades no están atadas a ningún lugar exterior al arte). Las verdades estéticas son irreductibles a otras verdades: las científicas, políticas o amorosas.

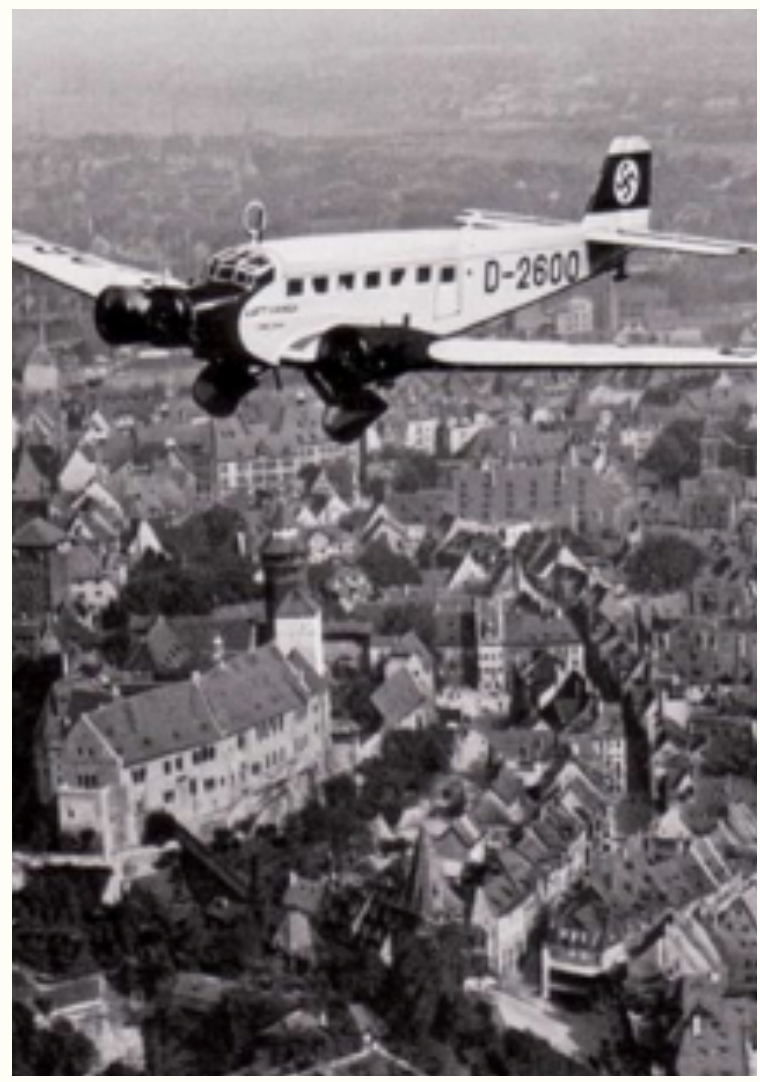

La actriz y realizadora alemana Leni Riefensthal es considerada una de las directoras de cine más innovadoras y destacables. Sólo que puso su genio al servicio de la causa del Partido Nacionalsocialista. El triunfo de la voluntad (1935), un documental sobre el mitin de varios días que llevó a cabo el partido nazi en la ciudad de Núremberg en 1934, es cinematográficamente deslumbrante, pero se trata de propaganda política al servicio de endiosar al Führer. En la secuencia de inicio en la que vemos un avión entre las nubes sobrevolando Núremberg, todos los recursos técnicos están puestos al servicio de la visitación de la idea de Adolf Hitler como enviado del destino que desciende de los cielos para encontrarse con su pueblo, conectando así la trascendencia (los cielos en los que sobrevuela un avión) con la inmanencia (el pueblo aglomerado en las calles de Núremberg), la eternidad con la temporalidad. 
El problema del planteo de verdades estéticas irreductibles en el campo del cine, es que no queda claro hasta qué punto puede separarse la forma y el contenido, la idea y su pasaje, de modo tal de que lo estético quede divorciado, por ejemplo, de lo político. Justamente en un arte de masas que ha sido utilizado tanto en esa vía.

Gran parte de la producción cinematográfica está hecha al servicio de un goce distractivo. No pretende ser arte ni pensamiento, sino objeto de consumo para el mercado. Se dirá de esos films que no constituyen objeto estético alguno sino un producto de los medios de masas en los que el cine construye una realidad ficcional divorciada de lo real, volviéndose instrumento de manipulación y propaganda. Pero tampoco se podría plantear al cine como arte es capaz de ser pasador de lo real a lo simbólico y denunciar las ilusiones ideológicas de la transparencia de la representación. En ambos casos se trataría de un uso político y no estético.

Los acontecimientos-verdad que produce el arte son para Badiou intrínsecos al arte mismo, rompiendo con determinada representación ideológica de lo que en un particular epocal se considera "estético". Una vez aceptado el planteo, el pensar-cine o la idea-cine de Badiou presenta una ambigüedad entre forma y contenido, que conduce a paradojas ético-estéticas. Un film puede ser mediocre para producir el pasaje de una idea al cine. Y entonces se dirá que es un film estéticamente malo. Pero un film puede ser al contrario formalmente admirable en el modo en que encadena imágenes y planos-secuencia para lograr el pasaje de una idea, y al mismo tiempo ser el pasaje de una idea repulsiva. Es el caso, por ejemplo, de El nacimiento de una nación (1915), de David Griffith. Los historiadores del cine coinciden en hacer de este film el nacimiento de la madurez del lenguaje cinematográfico, al punto que podría haberse titulado: "el nacimiento del lenguaje-cine". Pero al mismo tiempo, es un film brutalmente racista que elogia al Ku Klux Klan, una organización criminal dedicada a alentar el odio racial contra los afroamericanos. Al punto que el estreno del film de Griffith le dio nuevo impulso a la organización criminal, que para 1915 estaba en vías de desaparición. ¿Cómo sostener aquí al cine como producción de verdad separada del ámbito de lo político? ¿Qué composibilidad de verdades es posible entre lo estético y lo político?

\section{Del cine trágico al cine como imagen móvil de la eternidad}

Jean-Luc Godard en su Historia(s) del cine, piensa los 100 años de este arte nuevo desde una visión trágica del cine y del siglo XX. El director francés se pregunta: si la función del cine es hacer comprender la relación de una imagen con todas las demás, ¿cómo pensó el cine las relaciones reales e históricas del siglo XX? Y responde: como una relación con la muerte. El siglo XX es el siglo de los genocidios, las guerras mundiales, las bombas atómicas, la guerra fría, las ilusiones y utopías modernas destruidas por la muerte. De todo eso, el cine fue testigo porque propuso las relaciones que existían en el siglo XX entre los vivos y la muerte. Basta recorrer los diversos géneros cinematográficos (western, cine bélico, cine de terror, cine policial, etc.) para verificar que el cine está obsesionado por la relación de los vivos y los muertos. $\mathrm{Al}$ punto que el muerto-vivo es la figura de encarnación cinematográfica por excelencia. ${ }^{4}$

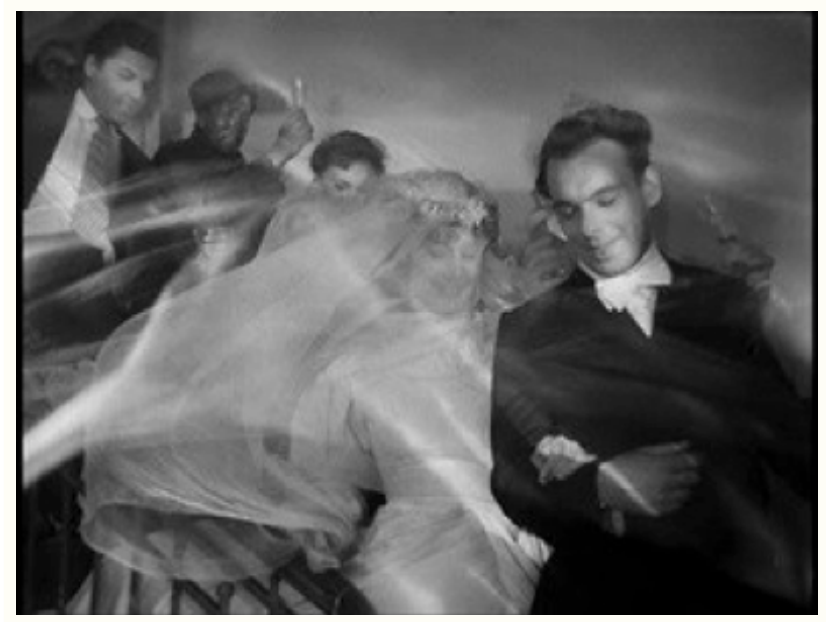

De las inabarcables representaciones de la muerte, desde las sublimes a las grotescas, desde las bellas a las ridículas, una de las más conmovedoras plasmaciones cinematográficas de la muerte es la escena de la muerte de Boris en Pasaron las grullas, film ruso de Mikhail Kalatozov, de 1957. Ambientada durante la Segunda Guerra Mundial, Boris es un soldado ruso que espera casarse con su amada Veronika cuando vuelva del frente. En medio de la estepa desolada, recibirá un disparo mortal. Kalatozov filma su muerte desde el punto de vista de lo que Boris ve, piensa y anhela, antes de caer abatido, haciéndonos así partícipes de la experiencia subjetiva de su muerte.

El cine del siglo XX jugó una función trágica similar a la tragedia griega, al poner las relaciones entre imágenes al servicio de las relaciones con la muerte. Al hacerlo, se volvió él mismo una aglomeración de cadáveres. Segura- 
mente hay más muertos en el cine que en toda la historia de la humanidad.

Badiou señala que a fines del Siglo XX, el cine fue tan lejos en la representación entre los vivos y los muertos que pasó de pensar la relación con la muerte a ofrecer el espectáculo de la muerte y el sufrimiento, en una suerte de Grand Guignol. Por razones económicas, la industria cinematográfica se puso al servicio de una falsa expresión trágica que se volvió explotación y regodeo en el mal, dando así fin de la era trágica del cine, al convertir la tragedia en brutalidad formal para un goce mórbido con la muerte. De ahí el planteo de Godard de la muerte del cine en tanto pensamiento-cine.

Para Badiou, en cambio, se trata de la muerte del cine trágico que piensa la relación con la muerte. La finalidad del cine no es mostrar imágenes, sino dar testimonio de un conjunto de relaciones de imágenes que no tienen que ver necesariamente con la muerte o que tengan que reducirse a comunicación. Si la comunicación es circulación de las cosas, el cine puede mostrar que entre las personas, grupos, objetos, puede haber relaciones que no se reducen a comunicación, donde lo decisivo es la relación misma como presencia pura que no desaparece terminada la comunicación.

Badiou propone un nuevo cine como arte consagrado a registrar la eternidad que hay en el tiempo. Un cine que partiendo del aquí y ahora, con nuestros problemas políticos, amorosos y existenciales, represente la inmovilidad oculta que hay en todo movimiento. Un cine como arte de la meditación de la eternidad en el sentido nietzscheano: aquello del presente que amerita permanecer, estar ahí, repetirse eternamente.

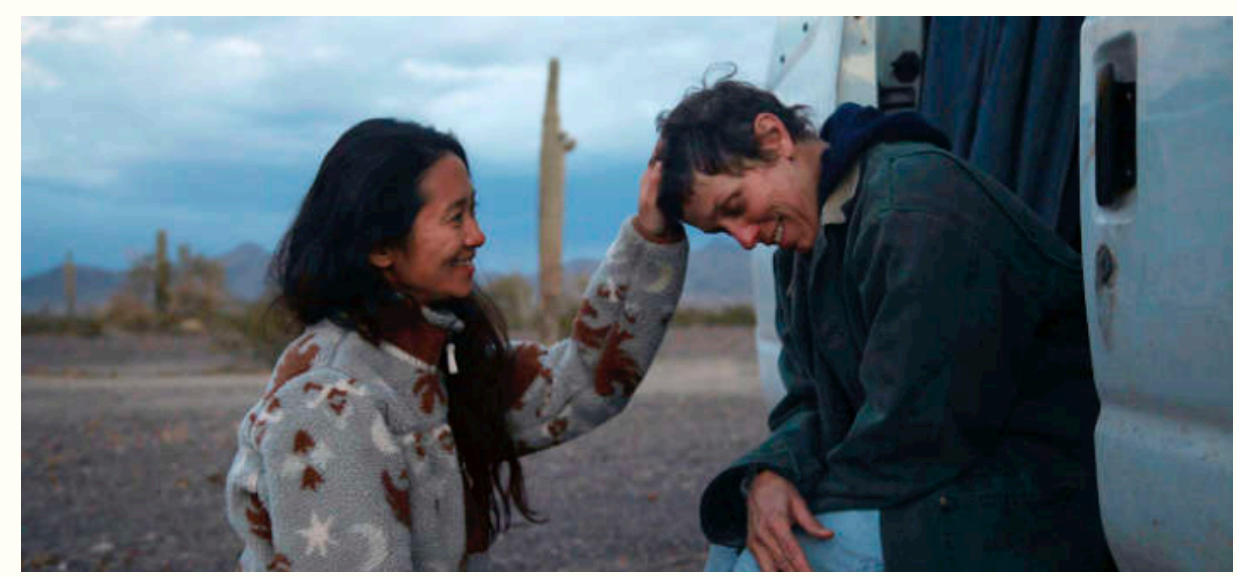

Este cine nuevo, es posible ya encontrarlo en la historia del cine: no todo el cine fue trágico y abocado a pensar la relación con la muerte. Es el caso los films de Robert Bresson o Yasujirô Ozu. Un ejemplo de un cine que revele lo trascendente inmóvil en el fondo de todo movimiento entre humanos es el film Nomadland (2020), de Chloé Zhao.

\section{Referencias}

Badiou, A. (2004). El cine como experimentación filosófica. En G. Yoel (comp.) Pensar el cine 1. Imagen, ética y filosofía. Manantial. Badiou, A. (2004). “El plus de ver”. En G. Yoel (comp.) Pensar el cine 2. Cuerpos, temporalidades y nuevas tecnologías. Manantial.

Badiou, A. (2009); Pequeño manual de inestética, Buenos Aires, Prometeo

Badiou, A. (2013); Cinema. Polity.

Badiou, A. (2014); El cine como acontecimiento. Paradiso.

Bazin, A. (1999); Qué es el cine. Rialp

Coen, E. y Coen, J. (directores). (1991). Barton Fink [película]. Circle Films, Working Title Films.

Griffith, D.W. (director). (1915). El nacimiento de una nación [película]. David W. Griffith Corp.

Kalatozov, M. (director). (1957). Pasaron las grullas [película].

Kubrick, S. (director). (2001). Odisea en el espacio [película]. Metro-Goldwyn-Mayer. 
Phillips, T. (director). (2019). Joker [película]. DC Films, Warner Bros. Pictures

Village Roadshow Pictures, Bron Creative, Joint Effort Productions, Sikelia Productions.

Renais, A. (director). (1961). El año pasado en Marienbad [película]. Cineriz.

Tarkovski, A. (director). (1979). Stalker [película]. Mosfilm.

Visconti, L. (director). (1971). Muerte en venecia [película]. Warner Bros.

Wenders, W. (director). (1975). El movimiento falso [película]. Wim Wenders Produktion, Solaris Film, Westdeutscher Rundfunk.

Zhao, C. (directora). (2020). Nomadland [película]. Searchlight Pictures

Fórum Hungary.

1 Que lo real en el cine son los films instala un debate con el planteo estético de Lacan en tanto concibe a lo real como lo imposible, por lo cual lo real en el cine quedaría ubicado en aquello que un film contornea o semidice a través del recurso cinematográfico. Un cine como pasador de lo real versus cine como pasaje de la idea.

2 El planteo de Godard es semiótico, al aludir a los ejes sintagmático y paradigmático que Ferdinand de Saussure planteaba para el signo en su Curso de Lingüística General: como el significante, una imagen aislada no tiene sentido. Una imagen siempre es una relación con otras imágenes. El cine conecta imágenes entre sí en una secuencia sintagmática, a la vez que remite a otras imágenes posibles en el eje paradigmático.

3 Así por ejemplo, La Orestíada de Esquilo, Edipo rey de Sófocles, o Hamlet de Shakespeare constituyen cada una de ellas un desarrollo e indagación en torno de la configuración literaria llamada tragedia.

$4 \quad$ No sólo por el personaje cinematográfico del zombie: ver cine clásico es efectivamente ver vivos a los muertos, dado que gran parte de los actores y actrices de los primeros 80 años del cine ya han fallecido. Los Bogart y las Marilyn se presentan como espectros de luz que surgen de la proyección cinematográfica entre los vivos que somos los espectadores, como en el relato La invención de Morel, de Bioy Casares. Es lo que André Bazin planteaba del cine como momificación y permanencia del pasado. 